\title{
Surveillance and prevention of major perioperative ischemic cardiac events in patients undergoing noncardiac surgery: a review
}

\author{
P.J. Devereaux, Lee Goldman, Salim Yusuf, Ken Gilbert, Kate Leslie, Gordon H. Guyatt
}

Abstract

THIS IS THE SECOND OF 2 ARTICLES EVALUATING cardiac events in patients undergoing noncardiac surgery. Unrecognized myocardial infarctions (MIs) are common, and up to $50 \%$ of perioperative MIs may go unrecognized if physicians rely only on clinical signs or symptoms. In this article, we summarize the evidence regarding monitoring strategies for perioperative $\mathrm{MI}$ in patients undergoing noncardiac surgery. Perioperative troponin measurements and 12-lead electrocardiograms can detect clinically silent MIs and provide independent prognostic information. Currently, there are no standard diagnostic criteria for perioperative Mls in patients undergoing noncardiac surgery. We propose diagnostic criteria that reflect the unique features of perioperative Mls. Finally, we review the evidence for perioperative prophylactic cardiac interventions. There is encouraging evidence that some perioperative interventions (e.g., $\beta$-blockers, $\alpha_{2}$-adrenergic agonists, statins) may prevent major cardiac ischemic events, but firm conclusions await the results of large definitive trials. The best evidence does not support a management strategy of preoperative coronary revascularization before noncardiac surgery.

CMAJ 2005;173(7):779-88

$\mathrm{T}$ his is the second of 2 articles in which we evaluate cardiac events in patients undergoing noncardiac surgery. In the first article, we established that patients undergoing noncardiac surgery frequently experience major perioperative cardiac events (i.e., cardiac death, nonfatal myocardial infarction [MI] and nonfatal cardiac arrest). ${ }^{1}$ We discussed the still unresolved pathophysiology of these events and suggested strategies for preoperative cardiac risk assessment and communication of risk. In this article, we summarize the evidence regarding monitoring strategies for periopera$\stackrel{0}{0}$ tive MI, propose diagnostic criteria for perioperative MI and review the evidence for perioperative prophylactic cardiac interventions.

The breadth of the topics covered in this article prohibited a fully systematic approach to this review. Although this is a narrative review, we did conduct thorough literature searches in each area and contacted the authors of relevant articles when necessary. We sought relevant systematic reviews and have highlighted their findings in our discussion.

\section{The difficulty in detecting perioperative myocardial infarctions}

Unrecognized MIs are not restricted to the perioperative setting. ${ }^{2}$ Eight large cohort studies (samples over 1000), which were not confined to patients undergoing surgery (e.g., the Framingham Study), evaluated the frequency of unrecognized MIs among more than 65000 people based on the new appearance of diagnostic Q waves (typically $\geq 30 \mathrm{~ms}$ in 2 or more anatomically adjacent leads). ${ }^{3-10}$ In these studies, 3237 MIs occurred, of which 945 (29\%; 95\% confidence interval [CI] 28\%$31 \%)$ were not detected at the time of the event. These MIs were not benign: patients experiencing an unrecognized MI have a prognosis similar to that of patients experiencing a recognized $\mathrm{MI} .^{11}$

To estimate the frequency of perioperative clinically unrecognized MI, we evaluated all prospective cohort studies of patients undergoing noncardiac surgery that fulfilled the following criteria: sample greater than 300 patients, surgery not restricted to a specific type (e.g., vascular surgery), at least 1 measurement of a cardiac enzyme or biomarker after surgery, and an accounting of the patients experiencing a perioperative MI who had no clinical signs or symptoms suggestive of an MI (Table 1). ${ }^{12-14}$ The pooled results from the 3 eligible studies suggest that only 14\% (95\% CI 3\%$25 \%$ ) of patients experiencing a perioperative $\mathrm{MI}$ will have chest pain and only $53 \%(95 \%$ CI $38 \%-68 \%)$ will have a clinical sign or symptom that may trigger a physician to consider an MI.

Although the number of events is small, the large proportion of clinically unrecognized MIs is plausible. First, the majority of perioperative MIs occur during the first 3 days after surgery, ${ }^{14,15}$ a period when most patients receive analgesics (e.g., narcotics), which can blunt cardiac pain perception. Second, a small but high-risk group of surgical patients will require intubation and sedation during the 
highest risk period, which limits their ability to communicate symptoms. Third, surgical patients experiencing potential signs (e.g., hypotension, tachycardia) or symptoms (e.g., shortness of breath, nausea) of MI have a host of more common potential explanations (e.g., atelectasis, pneumonia, hypovolemia, bleeding, medication side effect), and physicians may therefore not consider MI.

\section{Diagnosing perioperative MIs in patients undergoing noncardiac surgery}

Currently, there are no standard diagnostic criteria for perioperative $\mathrm{MI}$ in patients undergoing noncardiac surgery. Optimal diagnostic criteria must consider the unique features of perioperative MIs, in particular that a large proportion are clinically silent. We propose diagnostic criteria for perioperative MIs (Box 1) that we have adapted from a recent consensus document of the joint European Society of Cardiology / American College of Cardiology (ESC/ACC) committee that redefined nonperioperative $\mathrm{MI}^{16}$ (Box 2).

The first of our criteria requires a typical rise in troponin or a typical fall of an elevated troponin level detected at its peak after surgery in a patient without a documented alternative explanation for an elevated troponin level (e.g., pulmonary embolism) or - only if troponin measurement is unavailable - a rapid rise and fall of CK$\mathrm{MB}$. We encourage physicians to use troponin measure- ment, because perioperative CK-MB measurements are prone to false-positive and false-negative values. Surgical trauma can result in the release of CK-MB from skeletal muscle and a false-positive CK-MB value for MI. ${ }^{17-19} \mathrm{~A}$ substantial proportion of perioperative MIs occur in the first 2 days after surgery, when serum CK values are high secondary to surgical trauma. These high CK values can result in a low, and thus false-negative, ratio of CK-MB to total CK. ${ }^{19,20}$ Given the limitations of CK-MB measurement in the perioperative setting, physicians should only use CK-MB if troponin measurement is unavailable at their centre.

As troponin values rise, their variability, as measured by the coefficient of variation, decreases. The ESC/ACC guidelines define an increased troponin level as "a measurement exceeding the 99th percentile of a reference control group." At the same time, however, they specify that the coefficient of variation at the 99th percentile should be $10 \%$ or less. Unfortunately, no available troponin assay meets the $10 \%$ coefficient of variation criterion at the 99 th percentile - higher levels (above the 99th percentile) are required to meet this criterion..$^{21,22}$ In keeping with previous suggestions, ${ }^{21,23}$ until the assays are improved to meet the ESC/ACC recommendation, we define an increased troponin level as the lowest value that has a coefficient of variation equal to $10 \%$ (Appendix 1). ${ }^{21}$

New Q-wave changes ( $\geq 30 \mathrm{~ms})$ present in any 2 contiguous leads fulfill the definition of the development of

Table 1: Incidence of myocardial infarction (MI) and presence of signs or symptoms among patients undergoing noncardiac surgery

\begin{tabular}{|c|c|c|c|c|c|}
\hline \multirow[b]{2}{*}{ Study } & \multirow[b]{2}{*}{$\begin{array}{l}\text { No. of } \\
\text { patients }\end{array}$} & \multicolumn{3}{|c|}{$\begin{array}{l}\text { Incidence of Ml; no. }(\%) \\
\text { of patients }\end{array}$} & \multirow[b]{2}{*}{ Study definition of MI } \\
\hline & & Total & $\begin{array}{l}\text { With } \\
\text { chest pain }\end{array}$ & $\begin{array}{l}\text { With any sign } \\
\text { or symptom }\end{array}$ & \\
\hline $\begin{array}{l}\text { Mangano } \\
\text { et } \mathrm{al}^{12}\end{array}$ & 474 & $12(3)$ & $1(8)$ & $8(67)$ & $\begin{array}{l}\text { Elevated CK-MB value and } \\
1 \text { of the following: } \\
\text { - new Q-wave changes } \\
\text { - persistent ST-segment } \\
\text { and T-wave changes } \\
\text { - autopsy evidence }\end{array}$ \\
\hline Ashton et $\mathrm{al}^{13}$ & 512 & $8(2)$ & $2(25)$ & $5(62)$ & $\begin{array}{l}2 \text { of the following: } \\
\text { - new Q-wave changes } \\
\text { - elevated CK-MB value } \\
\text { - } \text { positive pyrophosphate } \\
\text { scan }\end{array}$ \\
\hline Badner et $\mathrm{al}^{14}$ & 323 & $18(6)$ & $3(17)$ & $7(39)$ & $\begin{array}{l}\text { Elevated CK level and } 2 \text { of } \\
\text { the following: } \\
\text { - elevated CK-MB/CK ratio } \\
\text { - new Q-wave changes } \\
\text { - elevated troponin level } \\
\text { - positive pyrophosphate } \\
\text { scan }\end{array}$ \\
\hline $\begin{array}{l}\text { Total }(\text { pooled } \\
\text { result)* }\end{array}$ & 1309 & $38(3)$ & $6(14)$ & $20(53)$ & - \\
\hline
\end{tabular}

Note: $\mathrm{CK}-\mathrm{MB}=$ creatine kinase $\mathrm{MB}$ isoenzyme.

*The results were pooled with the use of a fixed-effects model. The pooled results did not show significant heterogeneity (MI with chest pain, $p=0.57$ for heterogeneity; Ml with any sign or symptom, $p=0.24$ for heterogeneity). 
pathological Q waves. We define electrocardiogram (ECG) changes indicative of ischemia as ST-segment elevation ( $\geq 2 \mathrm{~mm}$ in leads $V_{1}, V_{2}$ or $V_{3}$ and $\geq 1 \mathrm{~mm}$ in the other leads) or ST-segment depression $(\geq 1 \mathrm{~mm})$ in at least 2 contiguous leads, or symmetric inversion of $\mathrm{T}$ waves $(\geq 1$ $\mathrm{mm}$ ) in at least 2 contiguous leads. Coronary artery intervention includes percutaneous coronary intervention or coronary artery bypass grafting (CABG).

Because many patients will not experience symptoms, clinicians may still miss the correct diagnosis in patients with an elevated troponin level after surgery who have experienced an MI. Some of these patients will have an uninterpretable ECG (e.g., paced, left bundle-branch block, chronic ST-segment changes); some will have an infarct in a territory (e.g., posterior) where the conventional ECG lacks sensitivity ${ }^{24}$ and some will have significant ST-segment changes that resolve by the time the ECG is repeated the following day. To avoid missing the diagnosis of MI, we have added to the first criterion the finding of a new or presumed new wall-motion abnormality on echocardiography or a new or presumed new fixed cardiac defect on radionuclide imaging.

When physicians encounter a patient who has an elevated troponin level after surgery without either ischemic symptoms or a diagnostic ECG, the differential diagnosis includes MI and noncardiac causes (e.g., pulmonary embolism). Because MI is a probable cause of an elevated tro-

Box 1: Proposed diagnostic criteria for perioperative myocardial infarction in patients undergoing noncardiac surgery

The diagnosis of perioperative MI requires any 1 of the following criterion:

- Criterion 1: A typical rise in the troponin level or a typical fall of an elevated troponin level detected at its peak after surgery in a patient without a documented alternative explanation for an elevated troponin level (e.g., pulmonary embolism); or a rapid rise and fall of CK-MB only if troponin measurement is unavailable.* This criterion requires that 1 of the following criteria must also exist:

- Ischemic signs or symptoms (e.g., chest, arm or jaw discomfort, shortness of breath, pulmonary edema)

- Development of pathological Q waves on an ECG

- ECG changes indicative of ischemia

- Coronary artery intervention

- New or presumed new cardiac wall-motion abnormality on echocardiography, or new or presumed new fixed defect on radionuclide imaging

- Criterion 2: Pathological findings of an acute or healing MI

- Criterion 3: Development of new pathological Q waves on an ECG if troponin levels were not obtained or were obtained at times that could have missed the clinical event

Note: $\mathrm{CK}-\mathrm{MB}=$ creatine kinase $\mathrm{MB}$ isoenzyme, $\mathrm{ECG}=$ electrocardiogram *Because CK-MB is both less sensitive and less specific in the perioperative setting compared with other settings and compared with troponin levels, it should be used for diagnostic purposes only when troponin levels are not obtainable. ponin level in this situation, physicians should consider obtaining an echocardiogram or radionuclide imaging.

Although physiologic studies suggest that an imaging study may be insensitive (an injury involving $>20 \%$ of myocardial wall thickness may be required to detect a wallmotion abnormality on echocardiography, and an injury of myocardial tissue $>10 \mathrm{~g}$ may be required to detect a radionuclide perfusion defect) ${ }^{16}$ at least 1 clinical study has suggested that echocardiography has a high sensitivity: 108 patients had troponin levels measured before surgery and every 6 hours for the first 36 hours after surgery, as well as echocardiography before surgery and 3-5 days after surgery. ${ }^{19}$ Echocardiography demonstrated a new wall-motion abnormality in all but 1 of the 9 patients who experienced an MI based on the diagnostic criteria of an elevated troponin level and significant ECG changes. This study also suggested excellent specificity for echocardiography. None of the remaining 99 patients had a new wall-motion abnormality. These results suggest that a wall-motion abnormality detected on an imaging study in the absence of a prior study suggests the diagnosis of perioperative MI, and a demonstrably new abnormality increases the likelihood further and thus supports our definition of a perioperative MI.

Further research is needed to evaluate the diagnostic criteria we propose.

\section{Prognostic factors}

\section{Cardiac biomarkers}

Perioperative measurement of cardiac enzymes or biomarkers not only can help to identify otherwise silent MI but may also contribute important prognostic information.

Box 2: Diagnostic criteria for nonperioperative myocardial infarction of the European Society of Cardiology / American College of Cardiology ${ }^{16}$

A. The diagnosis of acute, evolving or recent $\mathrm{MI}$ requires either of the following criterion:

- Criterion 1: A typical rise and gradual fall (troponin) or a more rapid rise and fall (CK-MB) of biochemical markers of myocardial necrosis with at least 1 of the following:

- Ischemic symptoms

- Development of pathological Q waves on an ECG

- ECG changes indicative of ischemia

- Coronary artery intervention

- Criterion 2: Pathological findings of an acute MI

B. The diagnosis of established MI requires either of the following criterion:

- Criterion 1: Development of new pathological Q waves on serial ECGs

- Criterion 2: Pathological findings of a healed or healing MI

Note: $\mathrm{CK}-\mathrm{MB}=$ creatine kinase $\mathrm{MB}$ isoenzyme, $\mathrm{ECG}=$ electrocardiogram. 
To assess the prognostic value of perioperative troponin and CK-MB measurements, we evaluated all noncardiac surgery studies that fulfilled the following criteria: at least 1 troponin or CK-MB measurement after surgery; reporting short-term ( $<30$ days after surgery) cardiac or total mortality, or intermediate ( $\leq 1$ year after surgery) or longterm (> 1 year after surgery) mortality or major cardiac events; and assessment of the prognostic value of perioperative troponin and CK-MB measurements through multivariable analysis.

The 6 eligible studies, ${ }^{25-30}$ which included a total of 2175 patients and 249 events (Table 2), evaluated CK-MB, ${ }^{26,27,29,30}$ troponin $\mathrm{T},{ }^{28-30}$ troponin $\mathrm{I}^{25,27}$ or both troponin $\mathrm{T}$ and $\mathrm{I} .{ }^{26} \mathrm{In}$ all 6 studies, troponin measurement proved to be a statistically significant independent predictor of intermediate and long-term outcomes (i.e., mortality and major cardiac events). This finding persisted even in the 2 studies that excluded patients who experienced a perioperative MI. 29,30 Two studies evaluated and demonstrated a dose-response relation - the higher the peak troponin value, the higher the 1-year mortality. ${ }^{25,28}$ In contrast, 3 of the 4 studies that assessed CK-MB failed to show an association between an elevated CK-MB value and intermediate or long-term outcomes. ${ }^{26,27,29,30}$

The authors of one of the studies ${ }^{27}$ published a second paper evaluating the same patients but excluding deaths in the first month after surgery and extending the follow-up period from 1 to 2 years. ${ }^{31}$ In this second paper, an elevated perioperative troponin value did not significantly predict the few deaths between months 1 to 24 after surgery (odds ratio $2.7,95 \%$ CI $0.7-10),{ }^{31}$ which suggests that an elevated perioperative troponin value more strongly predicts mortality in the first 12 months after surgery.

We did not evaluate the short-term predictive power of troponin or CK-MB values for diagnosing MI because they are now part of the diagnostic criteria. Troponin was not, however, part of the diagnostic criteria when one of the earlier studies showed its prognostic benefit. ${ }^{29}$

\section{Electrocardiography}

We evaluated studies using the same eligibility criteria for troponin and CK-MB measurement, made specific for electrocardiography, to assess the prognostic value of ECG evidence of perioperative ischemia. Because of the consistency with which an elevated perioperative troponin value proved to be an independent predictor of major outcomes after surgery, we also required that studies include troponin in their multivariable analysis. Three studies met our criteria (Table 3). ${ }^{26,27,30}$

Filipovic and colleagues ${ }^{27}$ did not demonstrate a statistically significant association between 3-lead ECG evidence of perioperative ischemia and mortality after surgery, probably because ECG monitoring with fewer leads has lower sensitivity than monitoring with 12 leads. ${ }^{32}$ The other 2 studies, one of which excluded patients who experienced an MI within 30 days after surgery, ${ }^{30}$ demonstrated a statistically significant association, independent of perioperative troponin values, between perioperative ischemia on a 12-lead ECG and long-term mortality..$^{26,30}$

Table 2: Prognostic value of perioperative troponin and CK-MB measurements in patients undergoing noncardiac surgery

\begin{tabular}{|c|c|c|c|c|c|}
\hline Study & $\begin{array}{l}\text { No. of } \\
\text { patients }\end{array}$ & Variables adjusted for in analysis & Primary outcome & $\begin{array}{l}\text { Association of } \\
\text { elevated troponin } \\
\text { level to outcome* }\end{array}$ & $\begin{array}{c}\text { Association of } \\
\text { elevated CK-MB } \\
\text { level to outcome* }\end{array}$ \\
\hline Kim et $\mathrm{al}^{25}$ & 229 & $\begin{array}{l}\text { Age, CHF, TAA surgery, } \\
\text { perioperative } \beta \text {-blocker therapy }\end{array}$ & Total mortality at $6 \mathrm{mo}(n=18)$ & OR $5.9(1.6-22)$ & NA \\
\hline $\begin{array}{l}\text { Landesberg } \\
\text { et } \mathrm{al}^{26}\end{array}$ & 447 & $\begin{array}{l}\text { Age, } \mathrm{MI} \text {, renal failure, type of } \\
\text { vascular surgery }\end{array}$ & Total mortality at $32 \mathrm{mo}(n=82)$ & OR $2.15(1.4-3.4)$ & OR $2.71(1.5-5)$ \\
\hline $\begin{array}{l}\text { Filipovic } \\
\text { et } \mathrm{al}^{27}\end{array}$ & 173 & $\begin{array}{l}\text { Age, renal failure, CHF, hypertension, } \\
\text { diabetes, anesthetic used, heart rate } \\
\text { variability, ECG evidence of } \\
\text { ischemia, elevated CK-MB value }\end{array}$ & Mortality at $12 \mathrm{mo}(n=28)$ & OR $10.2(2.8-37)$ & OR $6.9(0.8-56)$ \\
\hline $\begin{array}{l}\text { Oscarsson } \\
\text { et } \mathrm{al}^{28}\end{array}$ & 161 & $\begin{array}{l}\text { BMI, ASA score, perioperative } \\
\beta \text {-blocker and diuretic therapy, } \\
\text { perioperative tachycardia }\end{array}$ & Mortality at $12 \mathrm{mo}(n=22)$ & HR 15 (4-60) & NA \\
\hline \multicolumn{6}{|c|}{ Studies that excluded patients who had an MI before hospital discharge or within 30 days after surgery } \\
\hline $\begin{array}{l}\text { Lopez- } \\
\text { Jimenez et } \mathrm{al}^{29}\end{array}$ & 772 & $\begin{array}{l}\text { Age, sex, history of cardiac disease, } \\
\text { diabetes, smoking, type of surgery, } \\
\text { CK-MB level }\end{array}$ & $\begin{array}{l}\text { Composite outcome at } 6 \text { mo } \\
(n=19) \text { of cardiac death }(n= \\
\text { 14), nonfatal MI }(n=3) \text { and } \\
\text { unstable angina }(n=2)\end{array}$ & OR $4.6(p<0.05)$ & RR $1.2(0.5-3.2)$ \\
\hline Kertai et $\mathrm{al}^{30}$ & 393 & $\begin{array}{l}\text { Clinical risk score, ECG evidence } \\
\text { of ischemia }\end{array}$ & Mortality at $48 \mathrm{mo}(n=80)$ & HR $1.9(1.1-3.1)$ & HR $1.6(0.7-3.4)$ \\
\hline
\end{tabular}

Note: $\mathrm{ASA}=$ American Society of Anesthesiologists, $\mathrm{BMI}=$ body mass index, $\mathrm{CHF}=$ congestive heart failure, $\mathrm{CK}-\mathrm{MB}=$ creatine kinase $\mathrm{MB}$ isoenzyme, $\mathrm{ECG}=$ electrocardiogram, $\mathrm{HR}=$ hazard ratio, $\mathrm{MI}=$ myocardial infarction, $\mathrm{NA}=$ not assessed, $\mathrm{OR}=$ odds ratio, $\mathrm{RR}=$ relative risk, $\mathrm{TAA}=$ thoracoabdominal aneurysm.

*Numbers in parentheses are $95 \%$ confidence intervals, unless stated otherwise. 
The ECG, like biomarkers, is part of the diagnostic criteria for MI, but it also is often the sole criterion for myocardial ischemia in the absence of infarction. Even a single postoperative ECG demonstrating ischemia in the recovery room is predictive of a major cardiac complication later during the hospital stay. ${ }^{33}$

\section{Use of diagnostic and prognostic data}

If clinicians wish to avoid missing a significant proportion of perioperative MIs and identify patients at high risk of intermediate or long-term major cardiac events, they should consider monitoring troponin levels and ECGs daily during the first 3 days after surgery. Choosing whom to monitor presents a challenge. The risk of missing an asymptomatic infarct increases with increasing postoperative risk of major cardiac events. A reasonable threshold would be to obtain troponin levels and ECGs for patients with established atherosclerotic disease (i.e., coronary artery disease and peripheral vascular disease) who are undergoing surgery requiring hospital admission. An alternative threshold would be to monitor patients who have other risk factors for perioperative cardiac events (e.g., diabetes mellitus, renal insufficiency, or a history of heart failure or cerebrovascular disease). ${ }^{34}$ Definitive recommendations await the results of further studies.

\section{Interventions to prevent perioperative cardiac events}

The multiple triggers and states (i.e., inflammatory, hypercoagulable, hypoxic and stress states) that may result in an MI in patients undergoing noncardiac surgery, which we discussed in the first article in this series, ${ }^{1}$ open the possibility for a variety of potential prophylactic interventions. We will review the evidence for perioperative prophylactic use of $\beta$-blockers, calcium-channel blockers, $\alpha_{2}$-adrenergic agonists, coronary revascularization, 3-hydroxy-3-methyl-

Table 3: Prognostic value of ECG evidence of perioperative ischemia in patients undergoing noncardiac surgery

\begin{tabular}{llc}
\hline Study & ECG monitoring method & $\begin{array}{c}\text { Association of ECG } \\
\text { evidence with death } \\
\text { after surgery* }\end{array}$ \\
\hline $\begin{array}{l}\text { Landesberg } \\
\text { et al }^{26}\end{array}$ & $\begin{array}{l}\text { Continuous 12-lead ECG } \\
\text { monitoring for 48-72 h } \\
\text { after surgery }\end{array}$ & OR 2.20 $(p=0.03)$ \\
$\begin{array}{l}\text { Filipovic } \\
\text { et al }^{27}\end{array}$ & $\begin{array}{l}\text { Continuous 3-lead ECG } \\
\text { monitoring for 48 h after } \\
\text { surgery }\end{array}$ & OR 2.0 (0.3-12) \\
Kertai et al $^{30}$ & $\begin{array}{l}\text { 12-lead ECG on } \\
\text { postoperative days 2,3 } \\
\text { and 7 }\end{array}$ & HR 1.8 (1.0-3.1) \\
\hline
\end{tabular}

Note: $\mathrm{ECG}=$ electrocardiogram, $\mathrm{OR}=$ odds ratio, $\mathrm{HR}=$ hazard ratio.

${ }^{*}$ Numbers in parentheses are $95 \%$ confidence intervals, unless stated otherwise. glutaryl (HMG)-coenzyme A reductase inhibitors (i.e., statins) and acetylsalicylic acid (ASA) in patients undergoing noncardiac surgery (Table 4). ${ }^{35-46}$

In considering the evidence for these interventions, readers should keep in mind 2 points. First, it is only realistic to expect moderate treatment effects (i.e., relative risk reductions of $20 \%-35 \%)$. Even when an intervention effectively blocks one or more pathogenic mechanisms, there will remain a number of unaffected pathogenic mechanisms; thus, large treatment effects are unlikely. Second, even assuming a high rate of perioperative cardiovascular events of $10 \%$, trials need at least 350 , and ideally 650 , events to convincingly demonstrate a $25 \%$ relative risk reduction. ${ }^{47}$

\section{$\beta$-Blockers}

$\beta$-Blockers moderate the effects of increased catecholamine levels and therefore may prevent perioperative cardiac events. ${ }^{48,49}$ Many authors and 2 guideline committees have recommended that patients with coronary artery disease or risk factors for coronary artery disease undergoing noncardiac surgery receive perioperative $\beta$-blocker therapy. ${ }^{50-53}$ Important developments have occurred since these recommendations, and subsequent reviews, ${ }^{54,55}$ were published.

Proponents of $\beta$-blocker prophylaxis have based their recommendations primarily on the results of 2 randomized controlled trials (RCTs) (Table 4). ${ }^{35,37}$ These 2 trials have limitations. Poldermans and colleagues ${ }^{35}$ stopped their unblinded trial after an interim analysis based on 20 outcomes, and they demonstrated an implausible relative risk reduction of $90 \%$ in the composite outcome of cardiac death and nonfatal MI. In a second trial, by Mangano and colleagues, ${ }^{37}$ the results were no longer statistically significant when patients who died while receiving the study drug were included in the intention-to-treat analysis. ${ }^{56}$

In contrast, the results from 2 recent trials did not demonstrated any benefit from $\beta$-blocker therapy. ${ }^{36,38} \mathrm{Al}-$ though these 2 trials had a greater number of cardiac events and enrolled more patients than the 2 previous trials, they were nonetheless underpowered to determine the impact of $\beta$-blocker therapy on major cardiovascular outcomes. However, their findings indicate that the results from the earlier trials were overly optimistic. Ongoing tri$\mathrm{als}^{54}$ will help to resolve the inconsistency in the results of the current perioperative $\beta$-blocker trials.

\section{Calcium-channel blockers and $\alpha_{2}$-adrenergic agonists}

Calcium-channel blockers dilate coronary arteries; ${ }^{57} \alpha_{2}-$ adrenergic agonists suppress the release of catecholamines. ${ }^{42,58}$ These effects may prevent perioperative cardiac events. In Table 4 we present the results from 2 recent sys- 
Table 4: Results of studies evaluating the effectiveness of perioperative prophylactic cardiac interventions

\begin{tabular}{|c|c|c|c|c|c|c|}
\hline \multirow{2}{*}{$\begin{array}{l}\text { Intervention; } \\
\text { study }\end{array}$} & \multirow{2}{*}{$\begin{array}{l}\text { Study } \\
\text { design }\end{array}$} & \multirow[b]{2}{*}{ Outcome } & \multicolumn{2}{|c|}{$\begin{array}{l}\text { Group; no. of } \\
\text { events / no. of patients }\end{array}$} & \multirow{2}{*}{$\begin{array}{c}\mathrm{RR}^{*} \\
(95 \% \mathrm{Cl})\end{array}$} & \multirow[b]{2}{*}{ Comments } \\
\hline & & & Intervention & Control & & \\
\hline \multicolumn{7}{|c|}{$\beta$-blocker therapy } \\
\hline \multicolumn{7}{|c|}{ Short-term follow-up (30 d after surgery) } \\
\hline 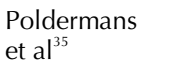 & $\mathrm{RCT}$ & $\begin{array}{l}\text { Cardiac death or } \\
\text { nonfatal MI }\end{array}$ & $2 / 59$ & $18 / 53$ & $\begin{array}{c}0.10 \\
(0.02-0.41)\end{array}$ & $\begin{array}{l}\text { Unblinded trial; stopped early after first interim } \\
\text { analysis }\end{array}$ \\
\hline Yang et $\mathrm{al}^{36}$ & RCT & $\begin{array}{l}\text { Cardiac death or } \\
\text { nonfatal MI }\end{array}$ & $19 / 246$ & $22 / 250$ & $\begin{array}{c}0.88 \\
(0.49-1.58)\end{array}$ & Blinded trial; not stopped after interim analysis \\
\hline \multicolumn{7}{|c|}{ Long-term follow-up } \\
\hline $\begin{array}{l}\text { Mangano } \\
\text { et } \mathrm{al}^{37}\end{array}$ & RCT & Total mortality at $2 \mathrm{yr}$ & $13 / 99$ & 23/101 & $\begin{array}{c}0.58 \\
(0.31-1.07)\end{array}$ & $\begin{array}{l}\text { Authors reported statistically significant result but } \\
\text { excluded patients who died while taking study drug. } \\
\text { Result was not significant after we included all deaths } \\
\text { in intention-to-treat analysis }\end{array}$ \\
\hline Juul et $\mathrm{al}^{38}$ & RCT & $\begin{array}{l}\text { Total mortality, MI, UA } \\
\text { or CHF at } 18 \mathrm{mo}\end{array}$ & $99 / 462$ & $93 / 459$ & $\begin{array}{c}1.06 \\
(0.82-1.36)\end{array}$ & $\begin{array}{l}\text { Authors included all events. Total mortality was the } \\
\text { same in both groups }(16 \%)\end{array}$ \\
\hline \multicolumn{7}{|c|}{ Calcium-channel blocker therapy } \\
\hline \multicolumn{7}{|c|}{ Short-term follow-up } \\
\hline \multirow[t]{2}{*}{$\begin{array}{l}\text { Wijeysundera } \\
\text { et } \mathrm{al}^{39}\end{array}$} & $\begin{array}{l}\text { MA of } \\
\text { RCTs }\end{array}$ & Total mortality & $5 / 358$ & $12 / 334$ & $\begin{array}{c}0.40 \\
(0.14-1.16)\end{array}$ & \multirow{2}{*}{$\begin{array}{l}\text { MA included } 11 \text { RCTs, of which } 8 \text { evaluated } \\
\text { diltiazem, } 2 \text { evaluated verapamil and } 2 \text { evaluated } \\
\text { dihydropyridines }\end{array}$} \\
\hline & & MI & $0 / 252$ & $5 / 234$ & $\begin{array}{c}0.25 \\
(0.05-1.18)\end{array}$ & \\
\hline
\end{tabular}

\section{$\alpha_{2}$-Adrenergic agonist therapy}

Short-term follow-up

\begin{tabular}{|c|c|c|c|c|c|c|}
\hline \multirow[t]{4}{*}{$\begin{array}{l}\text { Wijeysundera } \\
\text { et } \mathrm{al}^{40}\end{array}$} & \multirow[t]{4}{*}{$\begin{array}{l}\text { MA of } \\
\text { RCTs }\end{array}$} & $\begin{array}{l}\text { Total mortality } \\
\text { (vascular surgery) }\end{array}$ & $13 / 877$ & $26 / 771$ & $\begin{array}{c}0.47 \\
(0.25-0.90)\end{array}$ & \multirow{4}{*}{$\begin{array}{l}\text { Results were reported separately for patients who } \\
\text { underwent vascular surgery and those who underwent } \\
\text { nonvascular, noncardiac surgery. MA included } 12 \text { RCTs } \\
\text { of noncardiac surgery, of which } 8 \text { included vascular } \\
\text { surgery }\end{array}$} \\
\hline & & MI (vascular surgery) & $45 / 859$ & $65 / 757$ & $\begin{array}{c}0.66 \\
(0.46-0.94)\end{array}$ & \\
\hline & & $\begin{array}{l}\text { Total mortality } \\
\text { (nonvascular, } \\
\text { noncardiac surgery) }\end{array}$ & $16 / 512$ & $15 / 501$ & $\begin{array}{c}1.09 \\
(0.52-2.09)\end{array}$ & \\
\hline & & $\begin{array}{l}\text { MI (nonvascular, } \\
\text { noncardiac surgery) }\end{array}$ & $36 / 502$ & $26 / 491$ & $\begin{array}{c}1.35 \\
(0.83-2.21)\end{array}$ & \\
\hline \multirow[t]{2}{*}{ Oliver et al $^{41}$} & $\mathrm{RCT}$ & Total mortality & $91 / 946$ & $100 / 941$ & $\begin{array}{c}0.89 \\
(0.67-1.18)\end{array}$ & \multirow{2}{*}{$\begin{array}{l}\text { This trial was included in the MA by Wijeysundera } \\
\text { et al. }{ }^{40} \text { We included it here because it accounts for } \\
56 \text { of the } 70 \text { deaths and } 157 \text { of the } 172 \text { Mls in the MA }\end{array}$} \\
\hline & & $\begin{array}{l}\text { Total mortality or } \\
\text { nonfatal MI }\end{array}$ & $22 / 946$ & $34 / 941$ & $\begin{array}{c}0.61 \\
(0.35-1.03)\end{array}$ & \\
\hline \multicolumn{7}{|c|}{ Long-term follow-up (2 yr) } \\
\hline Wallace et $\mathrm{al}^{42}$ & $\mathrm{RCT}$ & Total mortality & $19 / 125$ & $19 / 65$ & $\begin{array}{c}0.43 \\
(0.21-0.89)\end{array}$ & $\begin{array}{l}\text { The trial evaluated the effect of } 4 \mathrm{~d} \text { of perioperative } \\
\text { clonidine therapy }\end{array}$ \\
\hline
\end{tabular}

Preoperative coronary artery revascularization

Long-term follow-up [2.7 yr])

McFalls et al ${ }^{43} \quad$ RCT $\quad$ Total motality

70/258 $67 / 252 \quad 0.98 \quad$ Of the patients assigned to coronary artery

(0.70-1.37) revascularization, 38\% underwent CABG, 55\% underwent $\mathrm{PCl}$, and $7 \%$ did not receive coronary revascularization

\section{Statin therapy}

6-mo follow-up after surgery

\begin{tabular}{|c|c|c|c|c|c|c|}
\hline Durazzo et $\mathrm{al}^{44}$ & RCT & $\begin{array}{l}\text { Cardiac death, nonfatal } \\
\mathrm{MI} \text {, ischemic stroke or UA }\end{array}$ & $4 / 50$ & $13 / 50$ & $\begin{array}{c}0.31 \\
(0.11-0.88)\end{array}$ & $\begin{array}{l}\text { None of the individual outcomes demonstrated } \\
\text { statistically significant results }\end{array}$ \\
\hline \multicolumn{7}{|c|}{ Antiplatelet therapy } \\
\hline \multicolumn{7}{|c|}{ Short-term follow-up } \\
\hline Robless et $\mathrm{al}^{45}$ & $\begin{array}{l}\text { MA of } \\
\text { RCTs }\end{array}$ & $\begin{array}{l}\text { Vascular death, nonfatal } \\
\text { MI, or nonfatal stroke }\end{array}$ & $76 / 893$ & $92 / 872$ & $\begin{array}{c}\text { OR } 0.76 \\
(0.54-1.05)\end{array}$ & $\begin{array}{l}\text { Patients underwent infra-inguinal bypass surgery. MA } \\
\text { included } 10 \mathrm{RCTs}, 6 \text { of which evaluated effects of ASA }\end{array}$ \\
\hline $\begin{array}{l}\text { PEP } \\
\text { investigators }{ }^{46}\end{array}$ & RCT & $\begin{array}{l}\text { Death from ischemic heart } \\
\text { disease or nonfatal MI }\end{array}$ & $105 / 6679$ & $79 / 6677$ & $\begin{array}{l}\text { HR } 1.33 \\
(1.00-1.78)\end{array}$ & $\begin{array}{l}\text { ASA therapy was evaluated in patients undergoing } \\
\text { surgical repair of hip fracture }\end{array}$ \\
\hline
\end{tabular}

Note: $\mathrm{ASA}=$ acetylsalicylic acid, $\mathrm{CABG}=$ coronary artery bypass grafting, $\mathrm{CHF}=$ congestive heart failure, $\mathrm{Cl}=$ confidence interval, $\mathrm{MA}=$ meta-analysis, $\mathrm{MI}=$ myocardial infarction, $\mathrm{PCl}=$ percutaneous coronary intervention, PEP trial = Pulmonary Embolism Prevention trial, RCT $=$ randomized controlled trial, UA $=$ unstable angina.

*Relative risks are reported, unless stated otherwise. 
tematic reviews and meta-analyses that evaluated the effects of perioperative calcium-channel blockers and $\alpha_{2}$-adrenergic agonists in patients undergoing noncardiac surgery. ${ }^{39,40}$ The results of the meta-analysis of calcium-channel blockers were not statistically significant; however, there were too few events from which to draw conclusions. ${ }^{39}$ More research is needed to determine the effect of perioperative calciumchannel blocker therapy.

A meta-analysis of $\alpha_{2}$-adrenergic agonists demonstrated a statistically significant reduction in both mortality and incidence of MI with $\alpha_{2}$-adrenergic agonist therapy among the patients who underwent vascular surgery. ${ }^{40}$ The investigators, however, found no effect on mortality and MI incidence among the patients who underwent nonvascular, noncardiac surgery.

Although there were 12 RCTs included in the metaanalysis of $\alpha_{2}$-adrenergic agonists, a single study accounted for most of the events. ${ }^{41}$ In this trial, 2854 patients were included in the randomization, but the published report excluded 957 of them at high risk of coronary artery disease because an interim analysis showed that they had a lower than expected event rate. The investigators then focused on the remaining 1897 patients with established coronary artery disease, $52 \%$ of whom underwent thoracic, abdominal or orthopedic surgery. Mivazerol therapy resulted in a statistically significant reduction in the composite outcome of total mortality and nonfatal MI only in the subgroup of patients who underwent vascular surgery.

An RCT completed since the publication of the metaanalysis of $\alpha_{2}$-adrenergic agonists evaluated the long-term effects of perioperative clonidine in patients undergoing noncardiac surgery. ${ }^{42}$ Clonidine was found to have no effect on the incidence of MIs (4 events) during the original hospital admission, but the trial results suggested a mortality benefit at 2 years after surgery.

Although the results of the meta-analysis of $\alpha_{2}-$ adrenergic agonists are encouraging, they warrant a cautious interpretation. The most recent clonidine trial is also encouraging, but given there were few events, unrealistic relative risk reductions and results of borderline statistical significance, the results may represent a chance finding. Confirmation of these results is required in a large, welldesigned trial.

\section{Coronary revascularization}

The use of coronary revascularization before noncardiac surgery is based on the assumption that perioperative MIs occur primarily in coronary arteries with hemodynamically significant stenoses and that revascularization may therefore prevent infarction. As we discussed in the first article in this series, ${ }^{1}$ this assumption may be erroneous.

Although some observational studies suggested a benefit of coronary revascularization before noncardiac surgery, ${ }^{59,60}$ a recent RCT has revealed that coronary revascu- larization performed in patients with chronic stable angina had no effect on outcomes after elective vascular surgery for abdominal aortic aneurysm or severe leg claudication (Table 4). ${ }^{43}$

This trial excluded patients with unstable angina, some of whom may benefit from coronary revascularization before noncardiac surgery. Small observational studies suggest that patients should have their noncardiac surgery delayed for at least 1 month following CABG and 6 weeks following angioplasty with a bare-metal stent. ${ }^{61-64}$ The optimal period to delay noncardiac surgery following use of a cardiac drug-eluting stent is unknown. ${ }^{65}$ However, it is probably substantially longer than 6 weeks, because drugeluting stents delay endothelialization compared with baremetal stents, and their use likely prolongs the period of risk for late stent-related thrombosis. ${ }^{66}$

\section{Statins}

Statins have plaque-stabilizing properties and therefore may prevent perioperative cardiac events. ${ }^{67}$ Three observational studies suggest that statin therapy reduces the risk of perioperative death in patients undergoing noncardiac surgery ${ }^{68-70}$ The 1 RCT that evaluated the effects of perioperative statin therapy in patients undergoing vascular surgery demonstrated a statistically significant benefit, but there were few events (Table 4). ${ }^{4+}$

Given the limited current evidence (i.e., 17 events in the only RCT, implausibly large relative risk reduction, borderline statistically significant result for a broad composite outcome), the effectiveness of perioperative statin therapy remains uncertain. The evidence does, however, provide the impetus for an adequately powered RCT to determine whether perioperative statin therapy prevents major perioperative cardiac events.

\section{Acetylsalicylic acid}

ASA suppresses platelet aggregation and therefore may prevent perioperative cardiac events. ${ }^{71}$ A systematic review of antiplatelet therapy versus placebo in patients undergoing infra-inguinal bypass surgery offers encouraging evidence that antiplatelet therapy prevents vascular events (Table 4). ${ }^{45}$ In contrast, the Pulmonary Embolism Prevention (PEP) trial suggested an increased risk of cardiac ischemic outcomes with ASA therapy in patients undergoing surgery for a hip fracture. ${ }^{46}$ Although the PEP trial suggests that ASA therapy can prevent pulmonary emboli (hazard ratio $0.43,95 \%$ CI $0.18-0.60$ ), this result has failed to affect clinical practice, because only $25 \%$ of patients in the placebo group were receiving a low-molecular-weight heparin. The American College of Chest Physicians' evidence-based guidelines recommend lowmolecular-weight heparin, not ASA, for prophylaxis against venous thromboembolism in patients undergoing hip fracture surgery. ${ }^{72}$ 
ASA therapy in patients undergoing noncardiac surgery is associated with an increased risk of bleeding. In the PEP trial, there were 197 postoperative bleeding episodes requiring a transfusion among the 6679 patients randomly assigned to receive ASA, compared with 157 postoperative bleeding episodes requiring a transfusion among the 6677 patients in the placebo group (relative risk increase $24 \%, 95 \%$ CI $1 \%-53 \%) .{ }^{46}$ In the antiplatelet trialists' overview of RCTs of antiplatelet therapy (ASA was the intervention in a third of these trials) in surgical patients, there were 28 nonfatal bleeding episodes requiring a transfusion among the 3798 patients receiving antiplatelet therapy, compared with 15 nonfatal bleeding episodes requiring a transfusion among the 3808 control subjects $(p=0.04) .^{73}$

Given the evidence that ASA prevents cardiovascular events in the nonperioperative setting, ${ }^{74}$ the conflicting RCT evidence surrounding the impact of ASA on perioperative cardiovascular events, and the likelihood of increased risk of bleeding associated with perioperative ASA therapy, determining the balance of benefits and risk of ASA prophylaxis in patients undergoing noncardiac surgery will require a large definitive RCT. Until then, physicians must weigh the increased risk of bleeding against yet unproven cardiovascular benefits.

\section{Acute and long-term management of major perioperative ischemic cardiac events}

Unfortunately, there are no RCTs informing us how to manage perioperative ischemic cardiac events acutely or in the long term. Identifying and treating correctable causes (e.g., anemia and hypoxia) seems advisable. Although thrombolytic, antiplatelet and anticoagulant therapies are beneficial in the management of acute nonoperative MIs, ${ }^{75}$ these therapies in the acute perioperative setting are likely to have a different risk-benefit ratio. Drugs that are efficacious in the long-term management of nonoperative MI (e.g., ASA, ACE inhibitors, $\beta$-blockers and statins) may not have the same impact in the management of perioperative MI. ${ }^{76}$ Only RCTs specific to the perioperative period will leave us confident of generalizing results from other settings.

\section{Conclusions}

Unrecognized MIs are common, and about half of all perioperative MIs may go unrecognized if physicians rely solely on clinical signs or symptoms. Perioperative troponin measurement and 12-lead ECGs can facilitate detection of clinically silent MIs as well as provide longterm prognostic information. Although several perioperative prophylactic interventions $\left(\alpha_{2}\right.$-adrenergic agonist, $\beta$-blocker, statin, ASA and calcium-channel blocker therapies) may prevent major perioperative cardiac events, de- finitively establishing or refuting their benefit will require large, well-designed and conducted trials. Current evidence does not support a management strategy of preoperative coronary revascularization before noncardiac surgery.

This article has been peer reviewed.

From the Departments of Medicine and of Clinical Epidemiology and Biostatistics (Devereaux, Guyatt, Yusuf) and the Population Health Research Institute (Yusuf), McMaster University, Hamilton, Ont., the Department of Medicine, University of California, San Francisco, San Francisco, Calif. (Goldman), the Department of Medicine, University of Western Ontario, London, Ont. (Gilbert), the Department of Anaesthesia and Pain Management, Royal Melbourne Hospital, and the Department of Pharmacology, University of Melbourne, Melbourne, Australia (Leslie)

Competing interests: None declared.

Contributors: P.J. Devereaux was responsible for the conception of the manuscript, the acquisition and analysis of the data and the writing the first draft. All of the authors contributed significantly to the manuscript's design and interpretation of the data, provided critical revisions to the manuscript and approved the final version.

Acknowledgements: P.J. Devereaux is supported by a Senior Research Fellowship Award from the Canadian Institutes of Health Research (CIHR). Salim Yusuf holds an endowed Chair of the Heart and Stroke Foundation of Ontario and is a Senior Scientist of CIHR.

\section{References}

1. Devereaux PJ, Goldman L, Cook DJ, Gilbert K, Leslie K, Guyatt GH. Perioperative cardiac events in patients undergoing noncardiac surgery: a review of the magnitude of the problem, the pathophysiology of the events and methods to estimate and communicate risk [review]. CMAJ 2005;173(6): 627-34.

2. Driscoll AC, Hobika JH, Etsten BE, Proger S. Clinically unrecognized myocardial infarction following surgery. N Engl 7 Med 1961;264:633-9.

3. Rosenman RH, Friedman M, Jenkins CD, Straus R, Wurm M, Kositchek R. Clinically unrecognized myocardial infarction in the Western Collaborative Group Study. Am 7 Cardiol 1967;19:776-82.

4. Medalie JH, Goldbourt U. Unrecognized myocardial infarction: five-year incidence, mortality, and risk factors. Ann Intern Med 1976;84:526-31.

5. Grimm RH Jr, Tillinghast S, Daniels K, Neaton JD, Mascioli S, Crow R, et al. Unrecognized myocardial infarction: experience in the Multiple Risk Factor Intervention Trial (MRFIT). Circulation 1987;75:II6-8.

6. Yano K, MacLean CJ. The incidence and prognosis of unrecognized myocardial infarction in the Honolulu, Hawaii, Heart Program. Arch Intern Med 1989;149:1528-32.

7. Kannel WB, Cupples LA, Gagnon DR. Incidence, precursors and prognosis of unrecognized myocardial infarction. Adv Cardiol 1990;37:202-14.

8. Sigurdsson E, Thorgeirsson G, Sigvaldason H, Sigfusson N. Unrecognized myocardial infarction: epidemiology, clinical characteristics, and the prognostic role of angina pectoris. The Reykjavik Study. Ann Intern Med 1995;122:96-102.

9. Jonsdottir LS, Sigfusson N, Sigvaldason H, Thorgeirsson G. Incidence and prevalence of recognised and unrecognised myocardial infarction in women. The Reykjavik Study. Eur Heart 7 1998;19:1011-8.

10. Sheifer SE, Gersh BJ, Yanez ND III, Ades PA, Burke GL, Manolio TA Prevalence, predisposing factors, and prognosis of clinically unrecognized myocardial infarction in the elderly. 7 Am Coll Cardiol 2000;35:119-26.

11. Sheifer SE, Manolio TA, Gersh BJ. Unrecognized myocardial infarction. Ann Intern Med 2001;135:801-11.

12. Mangano DT, Browner WS, Hollenberg M, London MJ, Tubau JF, Tateo IM. Association of perioperative myocardial ischemia with cardiac morbidity and mortality in men undergoing noncardiac surgery. The Study of Perioperative Ischemia Research Group. N Engl 7 Med 1990;323:1781-8.

13. Ashton CM, Petersen NJ, Wray NP, Kiefe CI, Dunn JK, Wu L, et al. The incidence of perioperative myocardial infarction in men undergoing noncardiac surgery. Ann Intern Med 1993;118:504-10.

14. Badner NH, Knill RL, Brown JE, Novick TV, Gelb AW. Myocardial infarction after noncardiac surgery. Anesthesiology 1998;88:572-8.

15. Fleischmann KE, Goldman L, Young B, Lee TH. Association between cardiac and noncardiac complications in patients undergoing noncardiac surgery: outcomes and effects on length of stay. Am J Med 2003;115:515-20.

16. Alpert JS, Thygesen K, Antman E, Bassand JP. Myocardial infarction redefined: a consensus document of the Joint European Society of Cardiology / American College of Cardiology Committee for the redefinition of myocardial infarction. 7 Am Coll Cardiol 2000;36:959-69.

17. Healey JH, Kagen LJ, Velis KP, Levine DB. Creatine kinase MB in skeletal mus- 
Perioperative cardiac events and noncardiac surgery

cle and serum of spine-fusion patients. Clin Orthop Relat Res 1985;(195):282-8.

18. Jules-Elysee K, Urban MK, Urquhart B, Milman S. Troponin I as a diagnostic marker of a perioperative myocardial infarction in the orthopedic population. 7 Clin Anesth 2001;13:556-60.

19. Adams JE III, Sicard GA, Allen BT, Bridwell KH, Lenke LG, Davila-Roman VG, et al. Diagnosis of perioperative myocardial infarction with measurement of cardiac troponin I. N Engl 7 Med 1994;330:670-4.

20. Haggart PC, Adam DJ, Ludman PF, Bradbury AW. Comparison of cardiac troponin I and creatine kinase ratios in the detection of myocardial injury after aortic surgery. Br 7 Surg 2001;88:1196-200.

21. Panteghini M, Pagani F, Yeo KT, Apple FS, Christenson RH, Dati F, et al. Evaluation of imprecision for cardiac troponin assays at low-range concentrations. Clin Chem 2004;50:327-32.

22. Sheehan P, Blennerhassett J, Vasikaran SD. Decision limit for troponin I and assay performance. Ann Clin Biochem 2002;39:231-6.

23. Apple FS, Wu AH, Jaffe AS. European Society of Cardiology and American College of Cardiology guidelines for redefinition of myocardial infarction: how to use existing assays clinically and for clinical trials. Am Heart 72002;144:981-6.

24. Zimetbaum PJ, Josephson ME. Use of the electrocardiogram in acute myocardial infarction. N Engl 7 Med 2003;348:933-40.

25. Kim LJ, Martinez EA, Faraday N, Dorman T, Fleisher LA, Perler BA, et al. Cardiac troponin I predicts short-term mortality in vascular surgery patients. Circulation 2002;106:2366-71.

26. Landesberg G, Shatz V, Akopnik I, Wolf YG, Mayer M, Berlatzky Y, et al. Association of cardiac troponin, $\mathrm{CK}-\mathrm{MB}$, and postoperative myocardial ischemia with long-term survival after major vascular surgery. 7 Am Coll Cardiol 2003;42:1547-54.

27. Filipovic M, Jeger R, Probst C, Girard T, Pfisterer M, Gurke L, et al. Heart rate variability and cardiac troponin I are incremental and independent predictors of one-year all-cause mortality after major noncardiac surgery in patients at risk of coronary artery disease. $7 \mathrm{Am}$ Coll Cardiol 2003;42:1767-76.

28. Oscarsson A, Eintrei C, Anskar S, Engdahl O, Fagerstrom L, Blomqvist P, et al. Troponin $\mathrm{T}$-values provide long-term prognosis in elderly patients undergoing non-cardiac surgery. Acta Anaesthesiol Scand 2004;48:1071-9.

29. Lopez-Jimenez F, Goldman L, Sacks DB, Thomas EJ, Johnson PA, Cook EF, et al. Prognostic value of cardiac troponin T after noncardiac surgery: 6month follow-up data. 7 Am Coll Cardiol 1997;29:1241-5.

30. Kertai MD, Boersma E, Klein J, Van Urk H, Bax JJ, Poldermans D. Longterm prognostic value of asymptomatic cardiac troponin $T$ elevations in patients after major vascular surgery. Eur 7 Vasc Endovasc Surg 2004;28:59-66.

31. Filipovic M, Jeger RV, Girard T, Probst C, Pfisterer M, Gurke L, et al. Predictors of long-term mortality and cardiac events in patients with known or suspected coronary artery disease who survive major non-cardiac surgery. Anaesthesia 2005;60:5-11.

32. Martinez EA, Kim LJ, Faraday N, Rosenfeld B, Bass EB, Perler BA, et al. Sensitivity of routine intensive care unit surveillance for detecting myocardial ischemia. Crit Care Med 2003;31:2302-8.

33. Rinfret S, Goldman L, Polanczyk CA, Cook EF, Lee TH. Value of immediate postoperative electrocardiogram to update risk stratification after major noncardiac surgery. Am 7 Cardiol 2004;94:1017-22.

34. Lee TH, Marcantonio ER, Mangione CM, Thomas EJ, Polanczyk CA, Cook $\mathrm{EF}$, et al. Derivation and prospective validation of a simple index for prediction of cardiac risk of major noncardiac surgery. Circulation 1999;100:1043-9.

35. Poldermans D, Boersma E, Bax JJ, Thomson IR, van de Ven LL, Blankensteijn JD, et al. The effect of bisoprolol on perioperative mortality and myocardial infarction in high-risk patients undergoing vascular surgery. Dutch Echocardiographic Cardiac Risk Evaluation Applying Stress Echocardiography Study Group. N Engl 7 Med 1999;341:1789-94.

36. Yang H, Raymer K, Butler R, Parlow J, Roberts R. Metoprolol after vascular surgery (MaVS) [abstract]. Can J Anaesth 2004;51(Suppl):A7.

37. Mangano DT, Layug EL, Wallace A, Tateo I. Effect of atenolol on mortality and cardiovascular morbidity after noncardiac surgery. Multicenter Study of Perioperative Ischemia Research Group. N Engl 7 Med 1996;335:1713-20.

38. Juul AB, Wetterslev J, Kofoed-Enevoldsen A, Callesen T, Jensen G, Gluud C. The Diabetic Postoperative Mortality and Morbidity (DIPOM) trial: rationale and design of a multicenter, randomized, placebo-controlled, clinical trial of metoprolol for patients with diabetes mellitus who are undergoing major noncardiac surgery. Am Heart 7 2004;147(4):677-83.

39. Wijeysundera DN, Beattie WS. Calcium channel blockers for reducing cardiac morbidity after noncardiac surgery: a meta-analysis [review]. Anesth Analg 2003;97:634-41.

40. Wijeysundera DN, Naik JS, Beattie WS. Alpha-2 adrenergic agonists to prevent perioperative cardiovascular complications: a meta-analysis [review]. $\mathrm{Am}$ J Med 2003;114:742-52.

41. Oliver MF, Goldman L, Julian DG, Holme I. Effect of mivazerol on perioperative cardiac complications during non-cardiac surgery in patients with coronary heart disease: the European Mivazerol Trial (EMIT). Anesthesiology 1999;91:951-61.

42. Wallace AW, Galindez D, Salahieh A, Layug EL, Lazo EA, Haratonik KA, et al. Effect of clonidine on cardiovascular morbidity and mortality after noncardiac surgery. Anesthesiology 2004;101:284-93.

43. McFalls EO, Ward HB, Moritz TE, Goldman S, Krupski WC, Littooy F, et al. Coronary-artery revascularization before elective major vascular surgery. NEngl 7 Med 2004;351(27):2795-804.

44. Durazzo AE, Machado FS, Ikeoka DT, De Bernoche C, Monachini MC, PuechLeao $\mathrm{P}$, et al. Reduction in cardiovascular events after vascular surgery with atorvastatin: a randomized trial. [discussion 975-6]. J Vasc Surg 2004;39:967-75.

45. Robless P, Mikhailidis DP, Stansby G. Systematic review of antiplatelet therapy for the prevention of myocardial infarction, stroke or vascular death in patients with peripheral vascular disease. Br J Surg 2001;88:787-800.

46. Prevention of pulmonary embolism and deep vein thrombosis with low dose aspirin: Pulmonary Embolism Prevention (PEP) trial. Lancet 2000;355:1295-302.

47. Yusuf S, Collins R, Peto R. Why do we need some large, simple randomized trials? Stat Med 1984;3:409-22.

48. Stone JG, Foex P, Sear JW, Johnson LL, Khambatta HJ, Triner L. Risk of myocardial ischaemia during anaesthesia in treated and untreated hypertensive patients. Br J Anaesth 1988;61:675-9.

49. Wallace A, Layug B, Tateo I, Li J, Hollenberg M, Browner W, et al. Prophylactic atenolol reduces postoperative myocardial ischemia. McSPI Research Group. Anesthesiology 1998;88:7-17.

50. Eagle KA, Berger PB, Calkins H, Chaitman BR, Ewy GA, Fleischmann KE, et al. ACC/AHA guideline update for perioperative cardiovascular evaluation for noncardiac surgery - executive summary: a report of the American College of Cardiology / American Heart Association Task Force on Practice Guidelines (Committee to Update the 1996 Guidelines on Perioperative Cardiovascular Evaluation for Noncardiac Surgery). 7 Am Coll Cardiol 2002;39:542-53.

51. Palda VA, Detsky AS. Perioperative assessment and management of risk from coronary artery disease. Ann Intern Med 1997;127:313-28.

52. Grayburn PA, Hillis LD. Cardiac events in patients undergoing noncardiac surgery: shifting the paradigm from noninvasive risk stratification to therapy. Ann Intern Med 2003;138:506-11.

53. Butterworth J, Furberg CD. Improving cardiac outcomes after noncardiac surgery. Anesth Analg 2003;97:613-5.

54. Devereaux PJ, Yusuf S, Yang H, Choi PT, Guyatt GH. Are the recommendations to use perioperative beta-blocker therapy in patients undergoing noncardiac surgery based on reliable evidence? [editorial] CMAJ 2004;171(3):245-7.

55. Auerbach AD, Goldman L. Beta-blockers and reduction of cardiac events in noncardiac surgery: scientific review [review]. 7AMA 2002;287:1435-44.

56. Swedberg K, Wedel H. Effect of atenolol on mortality and cardiovascular morbidity after noncardiac surgery [editorial]. Evidence-Based Cardiovasc Med 1998;2:33.

57. Abernethy DR, Schwartz JB. Calcium-antagonist drugs. N Engl 7 Med 1999 341:1447-57.

58. Ellis JE, Drijvers G, Pedlow S, Laff SP, Sorrentino MJ, Foss JF, et al. Premedication with oral and transdermal clonidine provides safe and efficacious postoperative sympatholysis. Anesth Analg 1994;79:1133-40.

59. Landesberg G, Mosseri M, Wolf YG, Bocher M, Basevitch A, Rudis E, et al. Preoperative thallium scanning, selective coronary revascularization, and long-term survival after major vascular surgery. Circulation 2003;108:177-83.

60. Eagle KA, Rihal CS, Mickel MC, Holmes DR, Foster ED, Gersh BJ. Cardiac risk of noncardiac surgery: influence of coronary disease and type of surgery in 3368 operations. CASS Investigators and University of Michigan Heart Care Program. Coronary Artery Surgery Study. Circulation 1997;96:1882-7.

61. Reddy PR, Vaitkus PT. Risks of noncardiac surgery after coronary stenting. Am 7 Cardiol 2005;95:755-7.

62. Wilson SH, Fasseas P, Orford JL, Lennon RJ, Horlocker T, Charnoff NE, et al. Clinical outcome of patients undergoing non-cardiac surgery in the two months following coronary stenting. 7 Am Coll Cardiol 2003;42:234-40.

63. Kaluza GL, Joseph J, Lee JR, Raizner ME, Raizner AE. Catastrophic outcomes of noncardiac surgery soon after coronary stenting. 7 Am Coll Cardiol 2000;35:1288-94.

64. Breen P, Lee JW, Pomposelli F, Park KW. Timing of high-risk vascular surgery following coronary artery bypass surgery: a 10-year experience from an academic medical centre. Anaesthesia 2004;59:422-7.

65. Auer J, Berent R, Weber T, Eber B. Risk of noncardiac surgery in the months following placement of a drug-eluting coronary stent [letter]. $7 \mathrm{Am}$ Coll Cardiol 2004;43:713; author reply 714-5.

66. Farb A, Heller PF, Shroff S, Cheng L, Kolodgie FD, Carter AJ, et al. Pathological analysis of local delivery of paclitaxel via a polymer-coated stent. Circulation 2001;104:473-9.

67. Nissen SE, Tuzcu EM, Schoenhagen P, Crowe T, Sasiela WJ, Tsai J, et al. Statin therapy, LDL cholesterol, C-reactive protein, and coronary artery disease. N Engl 7 Med 2005;352:29-38.

68. Lindenauer PK, Pekow P, Wang K, Gutierrez B, Benjamin EM. Lipid-lowering therapy and in-hospital mortality following major noncardiac surgery. 7AMA 2004;291:2092-9.

69. Poldermans D, Bax JJ, Kertai MD, Krenning B, Westerhout CM, Schinkel AF, et al. Statins are associated with a reduced incidence of perioperative mortality in patients undergoing major noncardiac vascular surgery. Circulation 2003;107:1848-51.

70. O’Neil-Callahan K, Katsimaglis G, Tepper MR, Ryan J, Mosby C, Ioannidis $\mathrm{JP}$, et al. Statins decrease perioperative cardiac complications in patients undergoing noncardiac vascular surgery: the Statins for Risk Reduction in Surgery (StaRRS) study. 7 Am Coll Cardiol 2005;45:336-42. 
71. McDaniel MD, Pearce WH, Yao JS, Rossi EC, Fahey VA, Green D, et al. Sequential changes in coagulation and platelet function following femorotibial bypass. 7 Vasc Surg 1984;1:261-8.

72. Geerts WH, Pineo GF, Heit JA, Bergqvist D, Lassen MR, Colwell CW, et al. Prevention of venous thromboembolism: the Seventh ACCP Conference on Antithrombotic and Thrombolytic Therapy. Chest 2004;126(3 Suppl):338S-400S.

73. Collaborative overview of randomised trials of antiplatelet therapy-III: Reduction in venous thrombosis and pulmonary embolism by antiplatelet prophylaxis among surgical and medical patients. Antiplatelet Trialists' Collaboration. BM7 1994;308:235-46.

74. Antithrombotic Trialists' Collaboration. Collaborative meta-analysis of randomised trials of antiplatelet therapy for prevention of death, myocardial in- farction, and stroke in high risk patients. BMJ 2002;324:71-86.

75. Danchin N, Urban P, De Benedetti E. Acute myocardial infarction. Clin Evid 2004;(12):20-50

76. Pignone M, Rihal C. Secondary prevention of ischaemic cardiac events. Clin Evid $2003 ;(10): 188-230$.

Correspondence to: Dr. P.J. Devereaux, Department of Clinical Epidemiology and Biostatistics, Faculty of Health Sciences, Rm. 2C8, McMaster University, 1200 Main St. W, Hamilton ON L8N 3Z5; fax 905905 526-1353; philipj@mcmaster.ca

\section{Appendix 1: Recommended troponin threshold* for myocardial infarction based on concentrations corresponding to a} coefficient of variation (CV) equal to $10 \% \dagger$

\begin{tabular}{|c|c|c|c|c|c|}
\hline Manufacturer; assay & Troponin & $\begin{array}{l}\text { Concentration } \\
\text { corresponding to } 10 \% \mathrm{CV} \\
\text { imprecision, } \mu \mathrm{g} / \mathrm{L}\end{array}$ & Manufacturer; assay & Troponin & $\begin{array}{l}\text { Concentration } \\
\text { corresponding to } 10 \% \mathrm{CV} \\
\text { imprecision, } \mu \mathrm{g} / \mathrm{L}\end{array}$ \\
\hline Abbott Diagnostics & & & Dade Behring & & \\
\hline AxSYM & I & 1.22 & Dimension $R x L$, second & & \\
\hline Bayer Diagnostics & & & generation & 1 & 0.26 \\
\hline ACS:180 & I & 0.37 & Opus, second generation & 1 & 0.90 \\
\hline Centaur & I & 0.33 & Stratus CS & 1 & 0.10 \\
\hline Immuno 1 & I & 0.34 & $\begin{array}{l}\text { Diagnostic Products } \\
\text { Corporation }\end{array}$ & & \\
\hline $\begin{array}{l}\text { Beckman Coulter } \\
\text { Access, second } \\
\text { generation }\end{array}$ & I & 0.06 & $\begin{array}{l}\text { Immulite One } \\
\text { Ortho-Clinical Diagnostics }\end{array}$ & 1 & 0.32 \\
\hline $\begin{array}{l}\text { Access 2, second } \\
\text { generation }\end{array}$ & I & 0.09 & $\begin{array}{l}\text { Vitros ECi } \\
\text { Roche Diagnostics }\end{array}$ & I & 0.44 \\
\hline BioMerieux & & & E 170 & $\mathrm{~T}$ & 0.04 \\
\hline $\begin{array}{l}\text { Vidas } \\
\text { Byk-Sangtec Diagnostica }\end{array}$ & I & 0.36 & $\begin{array}{l}\text { Elecsys } 1010 \text {, third } \\
\text { generation }\end{array}$ & $\mathrm{T}$ & 0.04 \\
\hline Liaison & I & 0.065 & $\begin{array}{l}\text { Tosoh Corporation } \\
\text { AIA-21, second generation }\end{array}$ & I & 0.09 \\
\hline
\end{tabular}

*If troponin levels cannot be obtained, no creatine kinase MB isoenzyme (CK-MB) threshold is of equivalent diagnostic accuracy. A threshold that physicians may want to use, if troponin measurement is unavailable, is a CK-MB value at the 99th percentile of a reference control group."

TThis appendix has been modified, with permission, from Table 3 in reference 21 (Panteghini M, Pagani F, Yeo KT, Apple FS, Christenson RH, Dati F, et al. Evaluation of imprecision for cardiac troponin assays at low-range concentrations. Clin Chem 2004;50:327-32). (O) 2004 American Association for Clinical Chemistry. 